\title{
DENDROBIOLOGY
}

2021, vol. 86, 56-68

https://doi.org/10.12657/denbio.086.006

\author{
Raj Kumar*, Rakesh Banyal, Awtar Singh, Rajender Kumar Yadav, \\ Parbodh Chander Sharma
}

\section{Salinity stress effects on the growth, morphological, physiological, and biochemical properties of Melia (Melia dubia Cav.) plant}

Received: 20 April 2021; Accepted: 24 September 2021

\begin{abstract}
Salinity stress severely affects the growth, physiological and developmental processes in plant species. Melia dubia is an ecologically and economically important tree species of the Indian subcontinent. However, systematic information with respect to the species salt tolerance potential is completely lacking. Under salt stress conditions, determining suitable soil EC range is required for the better survival, growth and productivity of the tree species. In present study, we investigated the effects of different soil salinity (EC 4, 8, and 12) levels on the ion homeostasis, physio-biochemistry, morphology, and growth of M. dubia plant. Results revealed that increase in soil salinity causes higher $\mathrm{Na}^{+}$content and $\mathrm{Na}^{+} / \mathrm{K}^{+}$ratio, while lower $\mathrm{K}^{+}$content, in the leaf tissues of $M$. dubia. The physiological processes such as the photosynthetic rate, stomatal conductance, internal $\mathrm{CO}_{2}$ concentration, and transpiration rate were adversely affected with the increased salt stress levels. Morphological parameters, such as internodal length, petiole length, leaf length, and leaf width also decreased $(\mathrm{P}<0.05)$ under saline stress conditions. Results further indicated that salinity levels significantly $(\mathrm{P}<0.05)$ affected the $M$. dubia growth, and the growth rate was found optimum upto $8 \mathrm{EC}$, thereafter it slightly decreased with the increased salt stress to $12 \mathrm{EC}$. Our findings showed that increased salinity stress causes significant changes in the physiological, morphological, and growth pattern of $M$. dubia. Therefore, based on present experiment, we found $M$. dubia suitable for the salt affected soils of EC 8 with optimum growth rate and at EC 12 with the moderate (20-25\%) growth reduction.
\end{abstract}

Keywords: Melia, salt stress, growth, physiology, phenology, biochemical

Address: R. Kumar, R. Banyal, A. Singh, R. Yadav, P. C. Sharma, ICAR-Central Soil Salinity Research Institute, Karnal-132001, Haryana, India, e-mail: rajcswcrti@gmail.com

*Corresponding author

\section{Introduction}

Plants growing under field conditions suffer from variety of stresses that severely affects their growth and productivity (Yuan et al., 2019). Among the environmental stressors, soil salts is one of the most detrimental abiotic stresses in plants (Flowers, 2004; Munns \& Tester, 2008). More importantly, area under salt-affected soils is expanding and spreading not only in India but also in the different regions of the world (Zhang, 2014; Bhardwaj et al., 2019). Even though limited land resource, available land is affected by the soil salts that consequently affects the biological processes and economic yield of plants. Moreover, due to shrinking agriculture land, rising tree products demand, decreasing crop productivity 
and increasing salinization globally, strong need are thereby felt to bring these lands under commercial tree plantations (Kumar et al., 2020).

Salt stress imposes more severe damage to plants as result of combination of ion toxicity, osmotic stress, nutrient deficiency, water imbalance, and unfavorable soil structure (Zhao, 2016; Sjoman et al., 2021). Saline soils mostly contain $\mathrm{Na}^{+}, \mathrm{K}^{+}, \mathrm{Ca}^{2+}$ and $\mathrm{Mg}^{2+}$ cations, and $\mathrm{Cl}^{-}$and $\mathrm{SO}_{4}{ }^{2-}$ anions, and the increased anions concentration leads to the high soil EC in the saline conditions (Zhang et al., 2006). High salt stress induced by non-essential toxic element in glycophytes modifies the various physio-biochemical and morphological traits, and reduces the growth of the exposed plants (Parida et al., 2019). Once tree species are exposed to high salt stress, their growth and productivity are severely affected, however, different soil EC levels can have contrasting effect on the plant physiological and growth processes (Banyal et al., 2017). Based on salt tolerance, tree species can be categorized as sensitive, moderately tolerant, highly tolerant and extremely high tolerant (Tomar et al., 2003; Dagar, 2014). Therefore, determining optimum range of salt tolerance in commercially important tree species is urgently required for obtaining the greater ecological and economic benefits, and for enhancing the overall productivity of salt affected soils.

Melia dubia Cav. is grown extensively in the tropical and subtropical regions of India, South East Asia, China, and Australia (Kumar et al., 2017). Species can be grown in all soil types of tropics and subtropics regions, receiving more than $500 \mathrm{~mm}$ annual rainfall, although species survival has also been reported in the drier areas receiving a low annual rainfall $(200 \mathrm{~mm})$ (Pradeep, 2015). It is a fast growing, multipurpose, industrially important, and has high ecological and economic value, which is extensively cultivated in different agroforestry systems of the several countries (Kumar et al., 2021a). In India, this species is expanding rapidly due to greater demand and acceptability among the farmers and industries. Because, Melia is used mostly in pulpwood, plywood, light timber, and medicinal industry, species is expected to rapidly occupy large areas of fertile and marginal salt affected lands (Parthiban et al., 2009). Therefore, $M$. dubia is considered as an outstanding tree for the plantation and agroforestry, as well as a good model plant among tree species for understanding the salt tolerance.

Understanding the salt tolerance potential of Melia is required to improve the land productivity, which is an important challenge for the researchers to cope with the issue of salt stress induced land degradation. The demand for the tree based products is increasing exponentially, and with the limited land availability need is thereby felt to bring unproductive salt affected soils under commercial tree plantations. Still, industries and stakeholders have not adopted Melia in salt affected soils; hence, strong opportunity exits to explore species potential in the such soils. Previous studies on the effect of salinity stress on Melia growth have been reported (Kumar et al., 2121b); however, no systematic information about the biochemical, physiological, morphological, phenological and growth aspect related to the salinity has been provided. A combination of these approaches may provide better insight in the salinity tolerance threshold of the species. The question about the range of salinity stress tolerance of Melia for achieving the best ecological and economic benefits is still left to be resolved. Furthermore, it would be interesting to determine the change in the biochemical, physiological and phenological at different EC levels. Assessment of growth performance under different salinity stress levels needs to be quantified to assess species suitability in salt affected soils to plan the suitable afforestation measures. The accomplishment of information about these issues will provide idea regarding the salt tolerance potential of Melia. Based on above studies, we hypothesized that soil salt causes accumulation of toxic ions that may results in a decline in the physiological process, alteration in phenology and thereby reduced plant growth of $M$. dubia. Therefore, the objectives of study were to observe the effect of salinity (i) on change in the ion homeostasis, physiological and biochemical parameters, and (ii) on the morphological modification, phenological altercation and growth dynamics of M. dubia. In the current investigation, we have first time reported an integrated study on change in biochemical, physiological, morphological, and growth pattern of $M$. dubia under long-term exposure to salinity stress to obtain an insight into the salt tolerance and physio-biochemical processes in species with a future aim to develop salt tolerant germplasm.

\section{Materials and Methods}

\section{Plant material}

Seeds of M. dubia were collected from US Nagar, Uttarakhand $\left(29^{\circ} 03^{\prime} \mathrm{N} ; 7^{\circ} 27^{\prime} \mathrm{E}\right.$ at $298 \mathrm{~m}$ asl) during February 2018. Seeds were sown in germination beds (soil and sand) and watered daily till the completion of germination. After 10 days, the seedlings were transplanted in polybags containing sand, soil and FYM (1:1:1) and watered every day.

\section{Experimental site}

The experiment was conducted during 2018$2019 \& 2019-2020$ at ICAR-CSSRI, Karnal, India 
$\left(29^{\circ} 84^{\prime} 30^{\prime \prime} \mathrm{N}, 76^{\circ} 85^{\prime} 80^{\prime \prime} \mathrm{E}\right)$ situated at $245 \mathrm{~m}$ above mean sea level. The climate of area is semi-arid characterized by winters from November to March and summers from April to October. A mean monthly maximum temperature of $38.6{ }^{\circ} \mathrm{C}$ during May, and the minimum of $5.8^{\circ} \mathrm{C}$ were recorded during the January. The mean annual precipitation was $1388 \mathrm{~mm}$, with $80 \%$ receives during the rainy season (July-September). Experiment was started during AugustSeptember (rainy season) which continued during October-November (autumn), December-January (winter), and February-March (spring), and terminated during April (summer) of the following year.

\section{Seedling transplanting}

For salinity treatments, the soil brought from outside was sieved, made homogenous and $10 \mathrm{~kg}$ soils filled in the each pots. In Aug 2018 and 2019, threemonth-old uniformly grown saplings of $M$. dubia were transplanted in plastic pots. Fifteen seedlings (replication) were planted in each treatment, and a total 60 seedlings were planted in the three EC (4, 8 , and 12) levels and in control. Seedlings were uniformly watered (every alternate day in summer and after four days in winter) and weeding operation was carried out every week.

\section{Imposition of salt stress}

We maintained three levels of salinity irrigation water stresses i.e. 4, 8, $12 \mathrm{EC} \mathrm{dS} / \mathrm{m}$ and a control. We brought saline water of $16 \mathrm{EC} \mathrm{dS} / \mathrm{m}$ from outside and stored in a plastic container for watering the seedlings. The required quantity of good quality water (2 EC) mixed with the saline water (16EC) for making the 4, 8, and 12 EC salinity levels. We alternatively applied saline and good quality water to distribute salt uniformly and to prevent excess accumulation of salts than the required in the treatments. Ionic composition of saline water used is presented in Table 1. We regularly monitored ECe of the soils for maintaining the above salinity levels. Beside EC, a control $(\mathrm{EC}=2.2 ; \mathrm{pH} 7.7)$ was also maintained which was irrigated with the good quality water.

\section{Measurement of soil EC}

The soil ECe (4, 8, and 12) of all the levels and control were measured every month. For that, $20 \mathrm{~g}$ of the dried, grinded, and sieved soil mixed with the $40 \mathrm{~mL}$ distilled water to make suspension. Electrical

Table 1. Ionic composition of saline water used in the study

\begin{tabular}{cccc}
\hline \multirow{2}{*}{$\mathrm{EC}$} & \multicolumn{3}{c}{ Ions (meq/L) } \\
\cline { 2 - 4 } $\mathrm{dSm}^{-1}$ & $\mathrm{Na}^{+}$ & $\mathrm{K}^{+}$ & $\mathrm{Ca}^{2+}+\mathrm{Mg}^{2+}$ \\
\hline Control & $3.64 \pm 0.54$ & $0.18 \pm 0.01$ & $6.52 \pm 1.57$ \\
4 & $26.84 \pm 4.51$ & $0.21 \pm 0.02$ & $13.10 \pm 3.54$ \\
8 & $58.64 \pm 8.41$ & $0.35 \pm 0.02$ & $30.14 \pm 6.87$ \\
12 & $110.54 \pm 14.50$ & $0.49 \pm 0.04$ & $50.47 \pm 12.40$ \\
\hline
\end{tabular}

conductance of soil saturation paste extract was measured using EC meter (Eutech Instruments, CON 700) in accordance with USSL (1954).

\section{Ionic analysis}

Fresh leaf samples were brought to laboratory, cleaned with distilled water, air dried and stored in paper envelopes. These leaf samples were oven dried at $60{ }^{\circ} \mathrm{C}$ to a constant weight. The $0.1 \mathrm{~g}$ dried samples were grinded and homogenized to fine power using the pestle and mortar and placed in a $25 \mathrm{~mL}$ volumetric flask. In each flask, $10 \mathrm{~mL}$ di-acidic mixture $\left(\mathrm{HNO}_{3}: \mathrm{HClO}_{4}, 3: 1\right.$, volume ratio) added and kept overnight, and next day sample were digested at $420^{\circ} \mathrm{C}$. The cooled samples were filtered through Whatman paper no. 42, and final volume made to $50 \mathrm{ml}$ by adding the deionized water. Aliquots of this solution were used for the determination of ions viz., $\mathrm{Na}^{+}, \mathrm{K}^{+}$by flame photometer (Systronics, 128) and $\mathrm{Ca}^{2+}, \mathrm{Mg}^{2+}, \mathrm{Zn}^{2+}, \mathrm{Mn}^{2+}, \mathrm{Fe}^{2+}$ and $\mathrm{Cu}^{2+}$ by atomic absorption spectrometry (ZEEnit $700 \mathrm{P}$, analytikjena, Germany).

\section{Physiological measurement}

Plant physiological parameters, such as intracellular $\mathrm{CO}_{2}$ concentration, photosynthetic rate, stomatal conductance, and transpiration rate were measured as the indicators of abiotic stress in plants. The observation was conducted on the fully developed leaves grown at different salinity levels. The measurements were carried out using LI-6800 Portable Photosynthesis System at the tri-monthly interval (Oct, Jan, April). For chlorophyll analysis, $200 \mathrm{mg}$ fresh leaves samples were taken and mixed with $3 \mathrm{ml}$ cooled acetone $(80 \%)$ in test tubes and centrifuged at $10000 \mathrm{rpm}$ for 10 minutes. The centrifuges supernatant was extracted and stored in the test tube and kept overnight after adding $10 \mathrm{ml}$ acetone. The absorbance of the samples was recorded at 645 and $663 \mathrm{~nm}$ in spectrophotometer. The chlorophyll concentration was calculated using the procedure given by Arnon's (1949). For determination of relative water content, top visible leaves were removed in morning and stored in ice humidified polythene bags. Fresh sample weight was recorded after removing all the dust particle, and sample were then soaked in distilled water for four hours. After this, leaves were dried using bloating paper and turgid weight was recorded. These leaves were further dried in oven at $60{ }^{\circ} \mathrm{C}$ for four hours to record the dry weight. The relative water content was measured using the procedure described by Barrs and Weatherly (1962). For analyzing the membrane injury, $10 \mathrm{ml}$ distilled water were added in ice-humidified samples for three hours and then initial electric conductivity of the solution were measured. Further, samples were kept in the water bath for 50 minutes to achieve the total killing 
tissue of tissues. The sample was cooled, and the final electric conductivity was recorded. The membrane stability was measured adopting the methodology described by Dionisio-Sene and Tobita (1962).

\section{Protein starch and sugar analysis}

The total soluble sugar was estimated as per the methodology described by Yemm and willis (1954). For this, $200 \mathrm{mg}$ leaf sample was grinded in $2.5 \mathrm{ml}$ ethanol (80\%) and $100 \mu \mathrm{l}$ extract was dissolved in 5 $\mathrm{ml}$ anthrone reagent $(0.4 \%)$. The mixture was heated in the water bath at $60^{\circ} \mathrm{C}$ for 10 minutes. After cooling, the absorbance was recorded at $620 \mathrm{~nm}$ against anthrone reagent (blank). The pellets of same extract were used for estimation of starch as per procedure described by Hassid and Neufeld (1964). The pellets were hydrolyzed with $2 \mathrm{ml}$ perchloric acid $(0.2 \mathrm{~N})$, and allowed to stand for 24 hours at $4{ }^{\circ} \mathrm{C}$. After centrifugation at $5000 \mathrm{rpm}$ for 15 minutes, $50 \mu \mathrm{l}$ of the supernatant was dissolved in $5 \mathrm{ml}$ anthrone reagent $(0.4 \%)$. The mixture was then heated at $60{ }^{\circ} \mathrm{C}$ for 10 minutes in the water bath and after cooling, absorbance was recorded at $620 \mathrm{~nm}$ against anthrone reagent (blank). For protein content estimation, $3 \mathrm{ml}$ Bradford was added to $100 \mu \mathrm{l}$ aliquot from the protein extract prepared in $1 \mathrm{~N} \mathrm{NaOH}$, and absorbance was recorded at $595 \mathrm{~nm}$ after 2 minutes and before 1 hour against the Bradford reagent (blank) as per the procedure described by Bradford (1976).

\section{Morphology and growth measurement}

The growth and morphological traits such as seedling height, collar diameter, number of leaves and branches, leaf length, leaf width, internodal length, and petiole length of each $M$. dubia seedlings were examined monthly during August to April, each during 2018-2019 and 2019-2020. Plant height was measured from base to apical shoot tips using a measurement scale. Collar diameter was measured at the base using a digital vernier caliper. The longest leaf at the first node below the apical meristem of shoots was used for the measurement of maximum leaf length $(\mathrm{mm})$, maximum leaf width $(\mathrm{mm})$ and petiole length $(\mathrm{mm})$ using the measurement scale. Additionally, three random seedlings were measured for internode length $(\mathrm{mm})$ between the third and fourth fully extended nodes from the apical meristem. Number of branches per plant, number of leaves per branch and bud formation was determined quantitatively. Apical shoot initiation measured when minimum of $0.5 \mathrm{~cm}$ shoot emerged after one week of first shoot appearance. All the parameters were recorded for each EC level and in control.

\section{Experimental design and data analysis}

All results were analyzed for three salinity levels and in control treatments. The data were subjected to one-way analysis of variance using SPSS 17.0 software (SPSS, Chicago, IL, USA). A p value smaller than 0.05 considered being statistically significant. Principal component analysis was performed for the thirty-two variable to determine factors contributing for the maximum variance using the component matrix value (MV).

\section{Results}

\section{Salinity stress affect cations accumulation}

We estimated the cations concentrations in leaves, stem, and root under varying salinity levels. Our results indicated that with the increased salinity stress, the $\mathrm{Na}^{+}$concentration of leaves, stem and root increased, while opposite trend was observed for the $\mathrm{K}^{+}$concentration $(\mathrm{P}<0.05$; Table 2$)$. Likewise, with the increasing soil salinity, the $\mathrm{Ca}^{2+}$ concentration decreased, while variable trends for $\mathrm{Mg}^{2+}$ content was observed in all the tissues. Among the

Table 2. Effects of salinity on mineral ion contents of leaf, stem, and root of $M$. dubia seedlings. (mean $\pm \mathrm{SD}, \mathrm{n}=15$ )

\begin{tabular}{|c|c|c|c|c|c|c|c|c|c|}
\hline $\begin{array}{l}\text { Plant } \\
\text { tissue }\end{array}$ & $\begin{array}{c}\text { Salinity } \\
\text { level } \\
(\mathrm{dS} / \mathrm{m})\end{array}$ & $\begin{array}{c}\mathrm{Na}^{+} \\
\left(\mathrm{mg} \mathrm{g}^{-1}\right)\end{array}$ & $\begin{array}{c}\mathrm{K}^{+} \\
\left(\mathrm{mg} \mathrm{g}^{-1}\right)\end{array}$ & $\begin{array}{c}\mathrm{Ca}^{2+} \\
\left(\mathrm{mg} \mathrm{g}^{-1}\right)\end{array}$ & $\begin{array}{c}\mathrm{Mg}^{2+} \\
\left(\mathrm{mg} \mathrm{g}^{-1}\right)\end{array}$ & $\begin{array}{c}\mathrm{Zn}^{2+} \\
\left(\mu \mathrm{g} \mathrm{g}^{-1}\right)\end{array}$ & $\begin{array}{c}\mathrm{Cu}^{2+} \\
\left(\mu \mathrm{g} \mathrm{g}^{-1}\right)\end{array}$ & $\begin{array}{c}\mathrm{Fe}^{2+} \\
\left(\mu \mathrm{g} \mathrm{g}^{-1}\right)\end{array}$ & $\begin{array}{c}\mathrm{Mn}^{2+} \\
\left(\mu \mathrm{g} \mathrm{g}^{-1}\right)\end{array}$ \\
\hline \multirow[t]{4}{*}{ Leaf } & Control & $2.68^{c} \pm 0.32$ & $20.27^{\mathrm{a}} \pm 3.54$ & $.17^{\mathrm{a}} \pm 1.54$ & $1.61^{\mathrm{b}} \pm 0.25$ & $12.78^{\mathrm{a}} \pm 4.15$ & $0.92^{\mathrm{b}} \pm 0.24$ & $52.86^{\mathrm{a}} \pm 6.38$ & $2.96^{a} \pm 0.54$ \\
\hline & EC 4 & $5.29^{b} \pm 0.42$ & $9.16^{\mathrm{b}} \pm 1.58$ & $5.01^{\mathrm{b}} \pm 0.78$ & $1.79^{\mathrm{b}} \pm 0$ & $10.07^{\mathrm{b}} \pm 3.24$ & $1.02^{\mathrm{b}} \pm 0.34$ & $39.11^{\mathrm{b}} \pm 8.54$ & $2.34^{\mathrm{b}}$ \\
\hline & EC 8 & $6.89^{\mathrm{ab}} \pm 1.10$ & 54 & $3.03^{c} \pm 0$ & $1.97^{\mathrm{a}} \pm$ & $6.97^{c} \pm 2.45$ & $1.22^{\mathrm{a} \pm}$ & $33.88^{\mathrm{bc}} \pm$ & $2.20^{\mathrm{b}}$ \\
\hline & EC 12 & $40^{\mathrm{a}} \pm 0.56$ & $2.80^{c} \pm 0.41$ & $2.95^{c} \pm 0.47$ & $2.02^{\mathrm{a}} \pm \mathrm{C}$ & $5.45^{\mathrm{c}} \pm 1.54$ & $1.26^{\mathrm{a}} \pm$ & $26.20^{c} \pm 4.56$ & $1.76^{\circ}$ \\
\hline \multirow[t]{4}{*}{ Stem } & Control & $26^{c} \pm 0.24$ & $13.99^{\mathrm{a}} \pm 2.58$ & $1.61^{\mathrm{b}} \pm 0.23$ & $0.59^{c} \pm 0.18$ & $7.85^{\mathrm{a}} \pm$ & $1.05^{\mathrm{b}}$ & $38.41^{\mathrm{ab} \pm}$ & 2.42 \\
\hline & EC 4 & $3.19^{c} \pm$ & $4.44^{\mathrm{b}} \pm$ & $1.78^{\mathrm{b}} \pm 0$ & $0.79^{c} \pm 0$ & $8.17^{a} \pm 3.24$ & $0.93^{b} \pm$ & $12.75^{\mathrm{c}} \pm$ & $2.47^{\mathrm{a}}$ \\
\hline & EC 8 & $5.01^{b} \pm 0.85$ & $3.44^{\mathrm{b}} \pm 0.56$ & $1.75^{\mathrm{b}} \pm 0.28$ & $1.04^{b} \pm 0.24$ & $5.03^{\mathrm{b}} \pm 1.74$ & $0.79^{c} \pm 0.24$ & $32.25^{\mathrm{b}} \pm 4.68$ & $1.81^{\mathrm{b}} \pm$ \\
\hline & EC 12 & $8.10^{\mathrm{a}} \pm 0.66$ & $3.03^{b} \pm 0.45$ & $3.50^{\mathrm{a}} \pm 0.76$ & $2.29^{a} \pm 0.57$ & $3.15^{c} \pm 0.57$ & $1.64^{a} \pm 0.29$ & $45.03^{\mathrm{a}} \pm 5.98$ & $1.06^{c} \pm 0.21$ \\
\hline \multirow[t]{4}{*}{ Root } & Control & $1.37^{\mathrm{d}} \pm 0.22$ & $6.76^{\mathrm{a}} \pm 1.25$ & $3.78^{\mathrm{a}} \pm 0.67$ & $1.12^{\mathrm{b}} \pm 0.24$ & $9.28^{\mathrm{a}} \pm 2.65$ & $1.59^{\mathrm{b}} \pm 0.38$ & $34.76^{b} \pm 3.65$ & $3.37^{\mathrm{a}} \pm 0.84$ \\
\hline & EC 4 & $4.86^{c} \pm 0.51$ & $6.15^{\mathrm{a}} \pm 1.12$ & $2.85^{\mathrm{b}} \pm 0.57$ & $1.29^{\mathrm{b}} \pm 0.33$ & $8.39^{\mathrm{a}} \pm 1.65$ & $1.28^{c} \pm 0.41$ & $35.58^{\mathrm{b}} \pm 4.85$ & $2.54^{b} \pm 0.64$ \\
\hline & EC 8 & $6.89^{b} \pm 0.39$ & $3.74^{\mathrm{b}} \pm 0.54$ & $2.88^{\mathrm{b}} \pm 0.52$ & $1.88^{\mathrm{a}} \pm 0.42$ & $6.26^{\mathrm{b}} \pm 2.01$ & $1.67^{b} \pm 0.33$ & $12.48^{c} \pm 2.65$ & $1.33^{c} \pm 0.54$ \\
\hline & EC 12 & $7.33^{\mathrm{a}} \pm 1.25$ & $3.92^{\mathrm{b}} \pm 0.48$ & $1.58^{c} \pm 0.28$ & $1.81^{a} \pm 0.52$ & $5.61^{\mathrm{b}} \pm 1.78$ & $2.38^{\mathrm{a}} \pm 0.68$ & $36.17^{\mathrm{a}} \pm 6.40$ & $1.39^{c} \pm 0.32$ \\
\hline
\end{tabular}

Means with similar latter are non-significantly different at $\mathrm{P}<0.05)$. 
micronutrients, increase in salinity causes decrease in $\mathrm{Zn}^{2+}$ and $\mathrm{Cu}^{2+}$, while variable trends for $\mathrm{Fe}^{2+}$ and $\mathrm{Mn}^{2+}$ concentration were observed in the three plant parts. The findings showed that the salt stress affected the cations accumulation in $M$. dubia seedlings.

\section{Soil salinity induces change in physiological processes}

We observed that all the physiological processes significantly declined along with the increased salt stress in plants. With increasing salinity levels from control to EC12, we observed a decrease $(\mathrm{P}<0.05$; Table 3) in the photosynthetic rate, stomatal conductance, internal $\mathrm{CO}_{2}$ concentration, and transpiration rate. Likewise, increase in salinity stress from EC 4 to $12 \mathrm{dS} / \mathrm{m}$ causes consistently decline in the chlorophyll content, relative water content, and increase in membrane injury of leaves $(\mathrm{P}<0.05 ;$ Fig. 5$)$, compared to control. These results indicated that salt treatment induced changes in physiological processes in the M. dubia seedlings.

\section{Salinity stress altered the plant biochemical}

We analyzed changes in biochemical parameters of $M$. dubia leaves under the salt stress by growing seedlings at different levels of salinity (EC). The results revealed that the non-significant $(\mathrm{P}<0.05$; Fig. 5) change in total starch was observed with the increasing salinity stress. Likewise, value of total sugar declined $(\mathrm{P}<0.05$; Fig. 2) with increased $\mathrm{EC}$ from 4 to $12 \mathrm{dS} / \mathrm{m}$, compared to control (EC $2 \mathrm{dS} / \mathrm{m}$ ). Likewise, protein content decreased to the level of $2.5 \%$ (4 dS/m), 3.5\% (8 dS/m), and 20\% (12 dS $/ \mathrm{m})$ with the increasing salt stress, compared to control. Therefore, salt treatments altered the biochemical characteristics in the M. dubia.

\section{Salinity stress modifies the plant morphology}

We observed the effect of salt stress on morphological and phenological parameters of Melia under varying level of salinity stress. These findings explained that salinity levels of EC 4,8 , and $12 \mathrm{dS} / \mathrm{m}$ reduced the internodal length (6-52\%), petiole length $(2-39 \%)$, leaf length $(7-23 \%)$ and width $(3-22 \%)$ in Melia, compared to control $(\mathrm{P}<0.05$; Fig. 4). Likewise, during spring season, the bud formation and apical shoot initiation was observed earlier at control ( $\mathrm{pH} 7.7$; EC $2 \mathrm{dS} / \mathrm{m}$ ), compared to rest of the salt stress levels. Therefore, our investigation demonstrated that the morphological parameters of $M$. $d u$ bia are modified under the salt stress conditions.

\section{Growth and Biomass of Melia decreases under salinity stress}

To investigate whether salt stress could influence seedling growth, we detected changes in diameter and height growth increment of seedlings at different levels of salt stress (EC) for the seven months. Our results observed that the reduction $(\mathrm{P}<0.05$; Fig. 1 $\& 2$ ) in height and diameter growth was minimum at EC 4 and maximum at EC12 dS/m, compared to control (EC 2). In quantitative terms, height and diameter growth at EC 4,8 , and 12 decreased by $4 \%$, $10 \%, 25 \%$, and $5 \%, 9 \%, 23 \%$, respectively, compared to control (EC $2 \mathrm{dS} / \mathrm{m})$. The values of the number of branches per plant and leaves per branch under salinity stress showed a decreasing trend initially and increasing trend later, which was related to the season of a month, except for increasing trend from September to October. We found that the branches (no.) and leaves (no.) significantly $(\mathrm{P}<0.05$; Fig. 1) reduced with increased salinity level from control to EC 12. Present outcome also explained that leaves, stem and biomass of seedlings were adversely affected at different salinity levels (EC), compared to control, and the decrease in $(\mathrm{P}<0.05$; Fig. 3$)$ these

Table 4. Proportion of total variability among different variable as explained by the principal components analysis

\begin{tabular}{crcc}
\hline \multirow{2}{*}{ Component } & \multicolumn{3}{c}{ Initial Eigenvalues } \\
\cline { 2 - 4 } & Total & \% of Variance & Cumulative \% \\
\hline 1 & 19.927 & 62.271 & 62.271 \\
2 & 2.924 & 9.139 & 71.409 \\
3 & 2.552 & 7.974 & 79.383 \\
4 & 1.948 & 6.086 & 85.469 \\
5 & 1.366 & 4.269 & 89.738 \\
6 & 1.226 & 3.832 & 93.570 \\
7 & 0.907 & 2.834 & 96.403 \\
8 & 0.518 & 1.617 & 98.021 \\
9 & 0.272 & 0.849 & 98.870 \\
10 & 0.226 & 0.706 & 99.575 \\
11 & 0.136 & 0.425 & 100.000 \\
\hline
\end{tabular}

Table 3. Effect of salinity on photosynthetic rate, stomatal conductance, internal $\mathrm{CO}_{2}$ concentration and transpiration rate in $M$. dubia (mean $\pm \mathrm{SD}, \mathrm{n}=15)$.

\begin{tabular}{|c|c|c|c|c|}
\hline & $\begin{array}{l}\text { Photosynthetic rate } \\
\qquad\left(\mu \mathrm{mol} \mathrm{m}^{-2} \mathrm{~s}^{-1}\right)\end{array}$ & $\begin{array}{l}\text { Stomatal conductance } \\
\left(\mathrm{mol} \mathrm{m} \mathrm{m}^{-2} \mathrm{~s}^{-1}\right)\end{array}$ & $\begin{array}{l}\text { Transpiration rate } \\
\left(\mathrm{m} \mathrm{mol} \mathrm{m} \mathrm{m}^{-2} \mathrm{~s}^{-1}\right)\end{array}$ & $\begin{array}{c}\text { Internal } \mathrm{CO}_{2} \text { concentration } \\
(\mathrm{ppm})\end{array}$ \\
\hline \multicolumn{5}{|c|}{ Salinity levels } \\
\hline Control & $35.5^{a} \pm 3.5$ & $0.51^{a} \pm 0.4$ & $8.1^{\mathrm{a}} \pm 1.2$ & $135.9^{\mathrm{a}} \pm 3.4$ \\
\hline EC 4 & $34.9^{\mathrm{a}} \pm 4.2$ & $0.48^{a} \pm 0.3$ & $6.0^{\mathrm{bc}} \pm 2.5$ & $124.0^{\mathrm{b}} \pm 5.2$ \\
\hline EC 8 & $29.1^{\mathrm{b}} \pm 4.9$ & $0.33^{b} \pm 0.3$ & $6.1^{\mathrm{bc}} \pm 1.8$ & $119.5^{\mathrm{b}} \pm 4.8$ \\
\hline EC 12 & $24.7^{\mathrm{bc}} \pm 3.2$ & $0.29^{b} \pm 0.3$ & $4.8^{c} \pm 2.2$ & $115.8^{c} \pm 3.5$ \\
\hline
\end{tabular}

Means with similar latter are non-significantly different at $\mathrm{P}<0.05)$. 

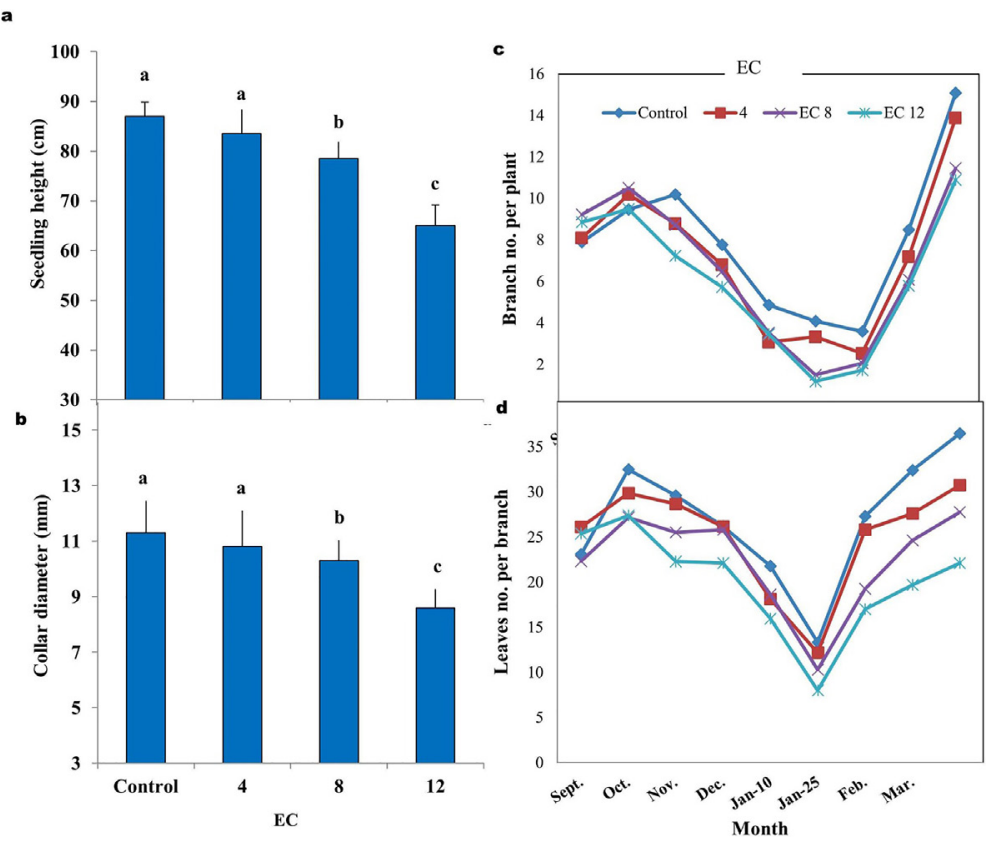

Fig 1. Effect of salinity (EC) on plant height (a), collar diameter growth (b), number of branches (c) and leaves (d) of $M$. dubia during different season (mean, $\mathrm{n}=15$ ). Bar with similar latter are non-significantly different at $\mathrm{P}<0.05$ )

parameters were highest (16-32\%) at EC 12, moderate $(15-25 \%)$ at EC 8 and low (5-10\%) at EC 4. These findings showed that the salinity stress adversely affected the growth and biomass of M. dubia.

\section{Principal component analysis}

Principal Components Analysis (PCA) is used to determine the most important factor (variable) contributing the variance and to approximate the relationships among a set of variables. The first eleven PCs together explained $84.02 \%$ of the total variation for different factors. The first principal component explained $62 \%$ of the entire variation, while first six PCs explained $93.5 \%$ of the total variation (Table 4 ). The variable, such as $\mathrm{K}^{+}$, apical shoot initiation, $\mathrm{Fe}^{2+}$, $\mathrm{Zn}^{2+}, \mathrm{Mn}^{2+}$, internodal length, petiole length, diameter, $\mathrm{Ca}^{2+}, \mathrm{Na}^{+}$, transpiration rate, total biomass, leaf biomass, bud initiation and height were the major contributor for the total variance in PCA1 with the matrix value $>0.9$ (Table 5 ). In second PCA, variable such as membrane injury, total starch, relative water content and chlorophyll content were the major

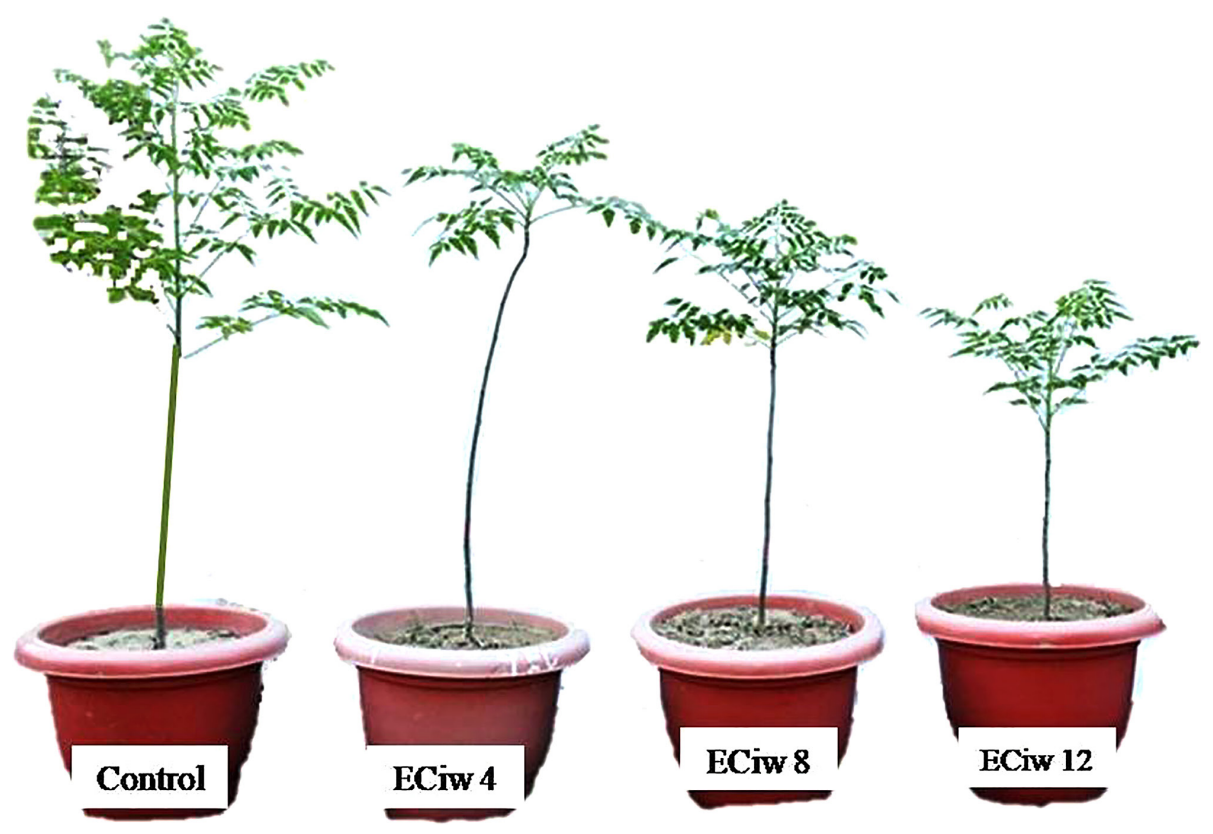

Fig. 2. Effect of salinity stress on performance of M. dubia 

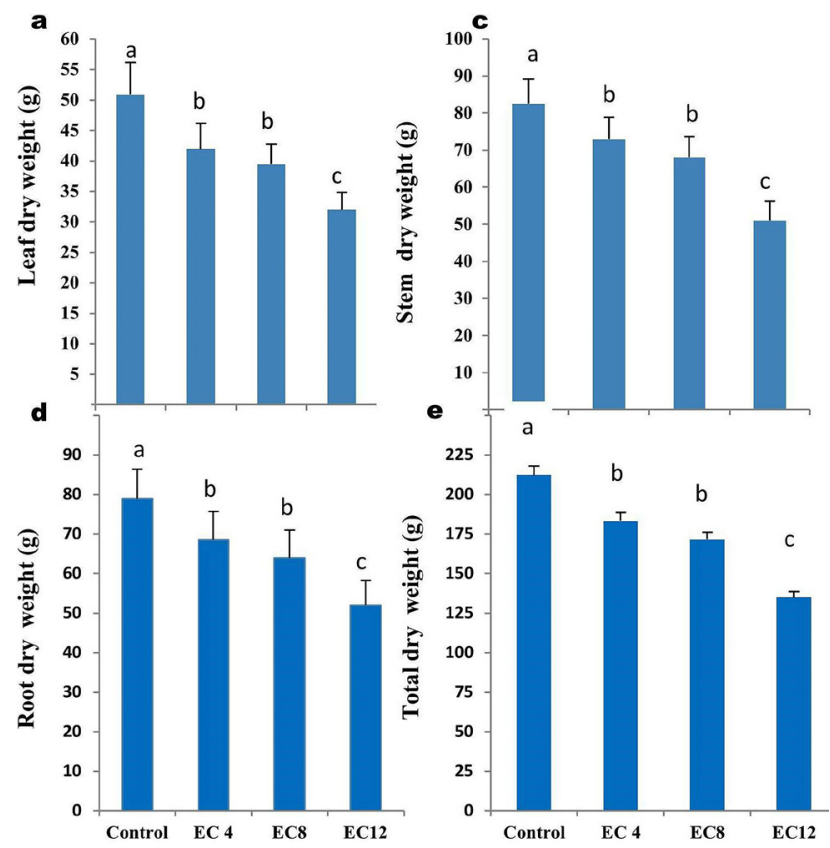

Fig 3. Salinity response of M. dubia for leaf biomass (a), root biomass (b), stem biomass (c) and total biomass (d) (mean, $\mathrm{n}=15$ ). Bar with similar latter are non-significantly different at $\mathrm{P}<0.05$ )
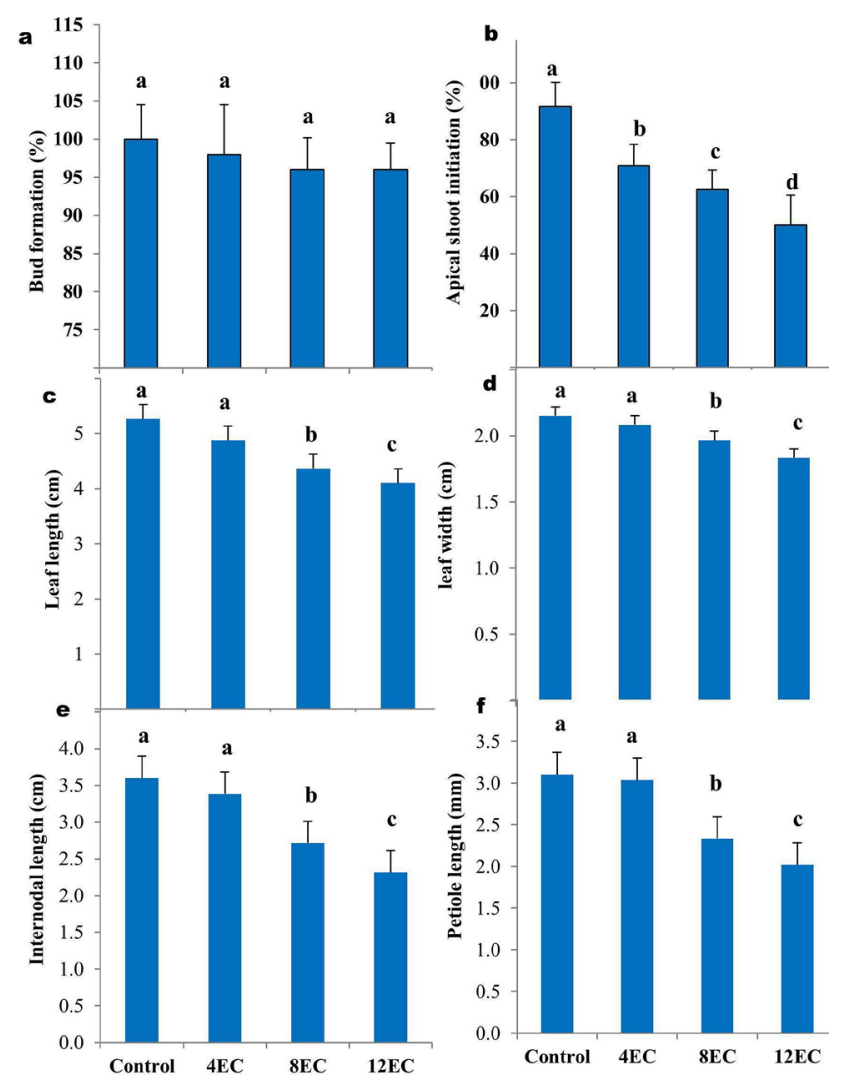

Fig 4. Effect of salinity on bud formation (a), apical shoot initiation (b), leaf length (a), leaf width (d), internodal length (e), and petiole length (f) (mean, $n=15$ ). Bar with similar latter are non-significantly different at $\mathrm{P}<0.05)$
Table 5. Component matrix value of major 6 principal components for different factors

\begin{tabular}{|c|c|c|c|c|c|c|}
\hline \multirow{2}{*}{ Factor } & \multicolumn{6}{|c|}{ Component } \\
\hline & 1 & 2 & 3 & 4 & 5 & 6 \\
\hline $\mathrm{K}^{+}$ & .981 & .108 & -.018 & .093 & .008 & .036 \\
\hline $\begin{array}{l}\text { Apical shoot } \\
\text { initiation }\end{array}$ & .977 & .043 & .102 & .056 & -.060 & -.095 \\
\hline $\mathrm{Fe}^{2+}$ & .976 & .036 & .131 & .022 & .092 & -.013 \\
\hline $\mathrm{Zn}^{2+}$ & .973 & -.056 & .050 & .165 & .103 & .056 \\
\hline $\mathrm{Mn}^{2+}$ & .963 & .072 & .001 & .027 & -.059 & -.194 \\
\hline $\begin{array}{l}\text { Internodal } \\
\text { length }\end{array}$ & .961 & .014 & -.066 & .161 & .068 & .169 \\
\hline Petiole length & .944 & -.195 & -.120 & .178 & .069 & .093 \\
\hline Diameter & .933 & -.098 & .014 & .087 & .162 & -.153 \\
\hline $\mathrm{Ca}^{2+}$ & .928 & -.116 & .210 & .098 & .172 & .003 \\
\hline $\mathrm{Na}^{+}$ & -.927 & .012 & .168 & -.165 & -.023 & -.215 \\
\hline $\begin{array}{l}\text { Transpiration } \\
\text { rate }\end{array}$ & .927 & -.033 & .060 & -.088 & -.223 & -.188 \\
\hline Total biomass & .909 & -.136 & -.162 & .079 & -.173 & -.123 \\
\hline Leaf biomass & .904 & .317 & .002 & -.078 & -.112 & .007 \\
\hline Bud initiation & .901 & -.124 & .075 & .176 & -.170 & .057 \\
\hline Height & .900 & .006 & .157 & -.020 & .106 & -.180 \\
\hline Root biomass & .899 & .171 & -.092 & .144 & .044 & -.154 \\
\hline Shoot biomass & .892 & .037 & -.163 & .095 & -.288 & -.074 \\
\hline Photosynthesis & .890 & .060 & -.281 & .019 & -.148 & .249 \\
\hline Total sugar & .888 & .007 & .169 & -.167 & -.027 & -.373 \\
\hline $\begin{array}{l}\text { Stomatal con- } \\
\text { ductance }\end{array}$ & .870 & .069 & -.005 & .138 & .275 & .351 \\
\hline $\mathrm{Cu}^{2+}$ & -.809 & .351 & -.112 & .229 & -.251 & .066 \\
\hline $\mathrm{Mg}^{2+}$ & -.753 & -.365 & .080 & .241 & .299 & -.341 \\
\hline Leaf length & .633 & .371 & .378 & -.171 & .401 & .026 \\
\hline $\begin{array}{l}\text { Internal } \mathrm{CO}_{2} \\
\text { conc. }\end{array}$ & -.581 & .363 & -.238 & .546 & -.142 & .180 \\
\hline $\begin{array}{l}\text { Membrane } \\
\text { injury }\end{array}$ & .296 & .796 & .254 & -.149 & -.101 & -.090 \\
\hline Total starch & -.031 & .670 & .534 & .297 & -.218 & .279 \\
\hline $\begin{array}{l}\text { Relative water } \\
\text { content }\end{array}$ & -.118 & -.602 & .558 & .201 & .065 & .453 \\
\hline Leaf width & .490 & -.499 & -.375 & .321 & -.253 & .013 \\
\hline Protein & .088 & -.160 & .864 & -.300 & -.149 & .111 \\
\hline $\begin{array}{l}\text { No. of Branch- } \\
\text { es }\end{array}$ & .257 & .178 & -.436 & -.749 & -.228 & .218 \\
\hline No. of leaves & .561 & -.281 & -.292 & -.565 & .200 & .351 \\
\hline $\begin{array}{l}\text { Chlorophyll } \\
\text { content }\end{array}$ & -.144 & .556 & -.433 & .117 & .621 & .028 \\
\hline
\end{tabular}

contributor (matrix value $>0.5$ ) for the variance. The variance for PCA3 (MV>0.5), PCA4 $(\mathrm{MV}>0.5)$, PCA5 (MV >0.4) and PCA6 (MV>0.3) were contributed mainly by three (total starch, relative water content and protein), two (Internal $\mathrm{CO}_{2}$ conc. and no. of leaves), two (leaf length and chlorophyll content), and four variable (Total sugar, stomatal conductance, $\mathrm{Mg}^{2+}$ and relative water content), respectively. 


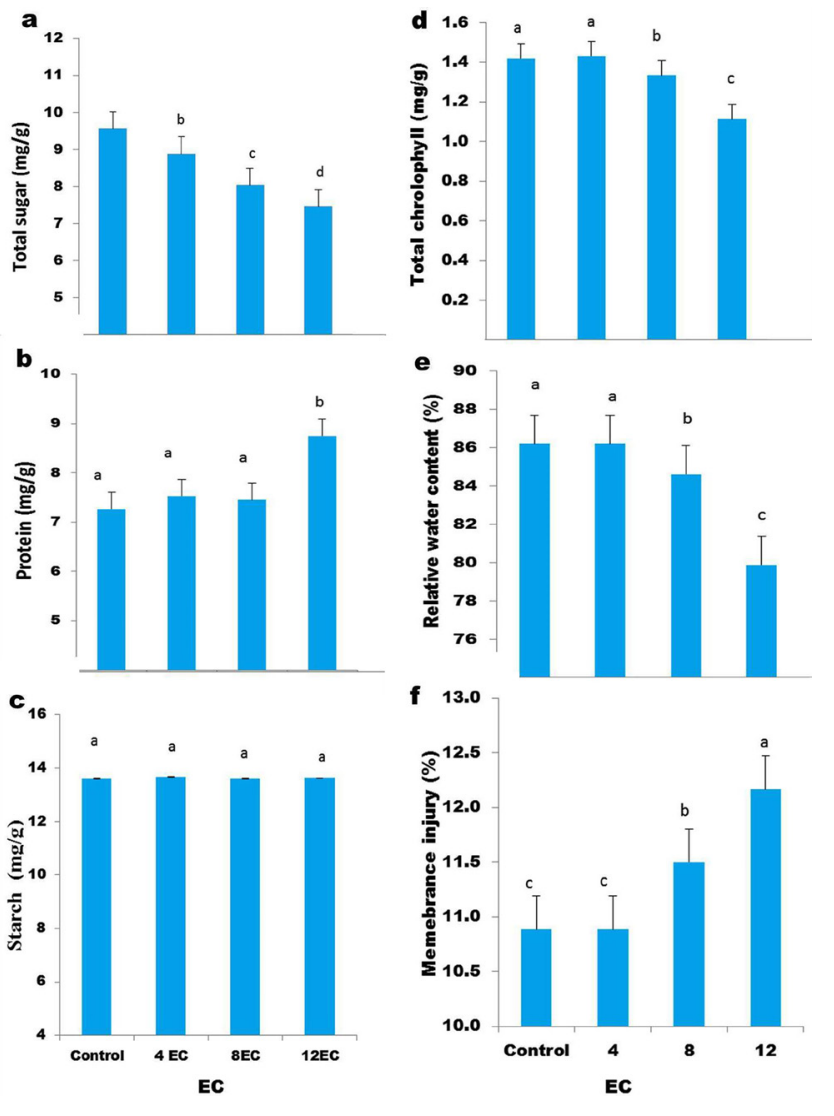

Fig 5. Salinity induced changes in total sugar (a), protein (b), starch (c), chlorophyll (d), relative water content (e), and membrane injury (f) (mean, $n=15)$. Bar with similar latter are non-significantly different at $\mathrm{P}<0.05$ )

\section{Discussion}

Salinity induced salt stress affects the survival, growth, and developmental processes of plant species (Banyal et al., 2017). Proper functioning of all the structural attributes and physiological processes of plants is required to produce the essential energy for their proper growth and development. However, once plants are exposed to salt stress, accumulation of toxic ions causes the physiological disruption, biochemical alteration, and morphological modification that affect the overall growth and development of plants (Fig. 6). Therefore, assessing species salt tolerance and determining suitable EC range for tree optimum growth is essentially required for planning afforestation programmes in the salt affected soils.

When plants are subjected to salt stress, ion homeostasis and nutrient imbalance are the primary physio-biochemical changes occur in plants. Present analysis revealed that with the increase in soil salinity from control to $12 \mathrm{EC}$, the $\mathrm{Na}^{+}, \mathrm{Cu}^{2+}$, and $\mathrm{Mg}^{2+}$ concentration increased, while a decrease in $\mathrm{K}^{+}, \mathrm{Ca}^{2+}, \mathrm{Zn}^{2+}, \mathrm{Fe}^{2+}$ and $\mathrm{Mn}^{2+}$ concentration was observed. It is well established that high concentrations of $\mathrm{Na}^{+}$can inhibit $\mathrm{K}^{+}$ and $\mathrm{Ca}^{2+}$ uptake, indicating existence of antagonism between these monovalent ions (Lemos et al., 2008). Our results are similar to the existing reports regarding the reduced uptake of $\mathrm{K}^{+}$and $\mathrm{Ca}^{2+}$ at moderate and high salt stress conditions; indicating the competition between the ions for the similar binding site at the exchange complex. Present findings showed decrease in $\mathrm{K}^{+}$content with the increasing $\mathrm{Na}^{+}$content; suggesting the competition between the both ions and replacement of $\mathrm{K}^{+}$by $\mathrm{Na}^{+}$at the reaction center. The physio-chemical similarity between both ions promotes ionic competition for binding sites on the membrane transporters (Zhu, 2003). Results further showed that per cent increase in $\mathrm{Na}^{+}$ions was greater at high salinity level (EC 12), compared to rest of the EC levels and control. The high salt stress in plant growth medium reduces $\mathrm{K}^{+}$content, and enhance $\mathrm{Na}^{+}$ uptake and accumulation, causing the efflux and leakage of $\mathrm{K}^{+}$ions from the plant cells (Azooz et al., 2015). Under such conditions, $\mathrm{Na}^{+}$content rises above that of $\mathrm{K}^{+}$which causes the poor nutrient uptake and lack of $\mathrm{Na}^{+} / \mathrm{K}^{+}$homeostasis (Latef et al., 2016). A slightly higher EC than the ideal level of ions toxicity adversely affects the physio-biochemical processes, including mineral uptake, photosynthesis, membrane integrity and plants growth (Chen et al., 2012 and Hazman et al., 2016). A critical limit of $\mathrm{Na}^{+}$in leaf tissue need to be fixed, above which it has toxic effect on the plant growth and development. The $\mathrm{Na}^{+}$ions damage various plant systems that absorb and utilize $\mathrm{Ca}^{2+}$ and $\mathrm{K}^{+}$ions in plant tissues, thereby adversely affects the plant growth and development, as both ions are essential for the various physio-biochemical processes (Hilge, 2012; Demidchik \& Maathuis, 2007). Results further showed that with increased salinity stress, the $\mathrm{Ca}^{2+}$ content decreased in leaf tissues, while opposite trend was noticed for $\mathrm{Mg}^{2+}$ concentration. As both ions showed competitiveness to each other at tissue and cell level, the increase in $\mathrm{Mg}^{2+}$ concentration causes $\mathrm{Ca}^{2+}$ deficiency that could adversely affect the plant physiological processes. The decrease in $\mathrm{Ca}^{2+}$ with increased salt stress alters the cell wall rigidity and plasma membrane integrity (Maathuis, 2009). During this period, $\mathrm{Ca}^{2+}$ transporters play an important role in regulating cellular $\mathrm{Ca}^{2+}$ levels to cope with salinity stresses. Moreover, the increased $\mathrm{Mg}^{2+}$ content in salt stressed plants benefits the chlorophyll synthesis, enzyme activation, and the stabilization of nucleotides and nucleic acids to cope the salt stresses (Maathuis, 2009). Hence, increased accumulation of toxic ions and nutrient imbalance may greatly affect the physiological processes in Melia.

Maintaining structural integrity and orderliness of the chloroplast is necessary for the proper functioning of plants physiological processes. It is observed that many stressors induces structural changes in photosynthetic apparatus, that reduces the photochemical efficiency and electron transport activity of 


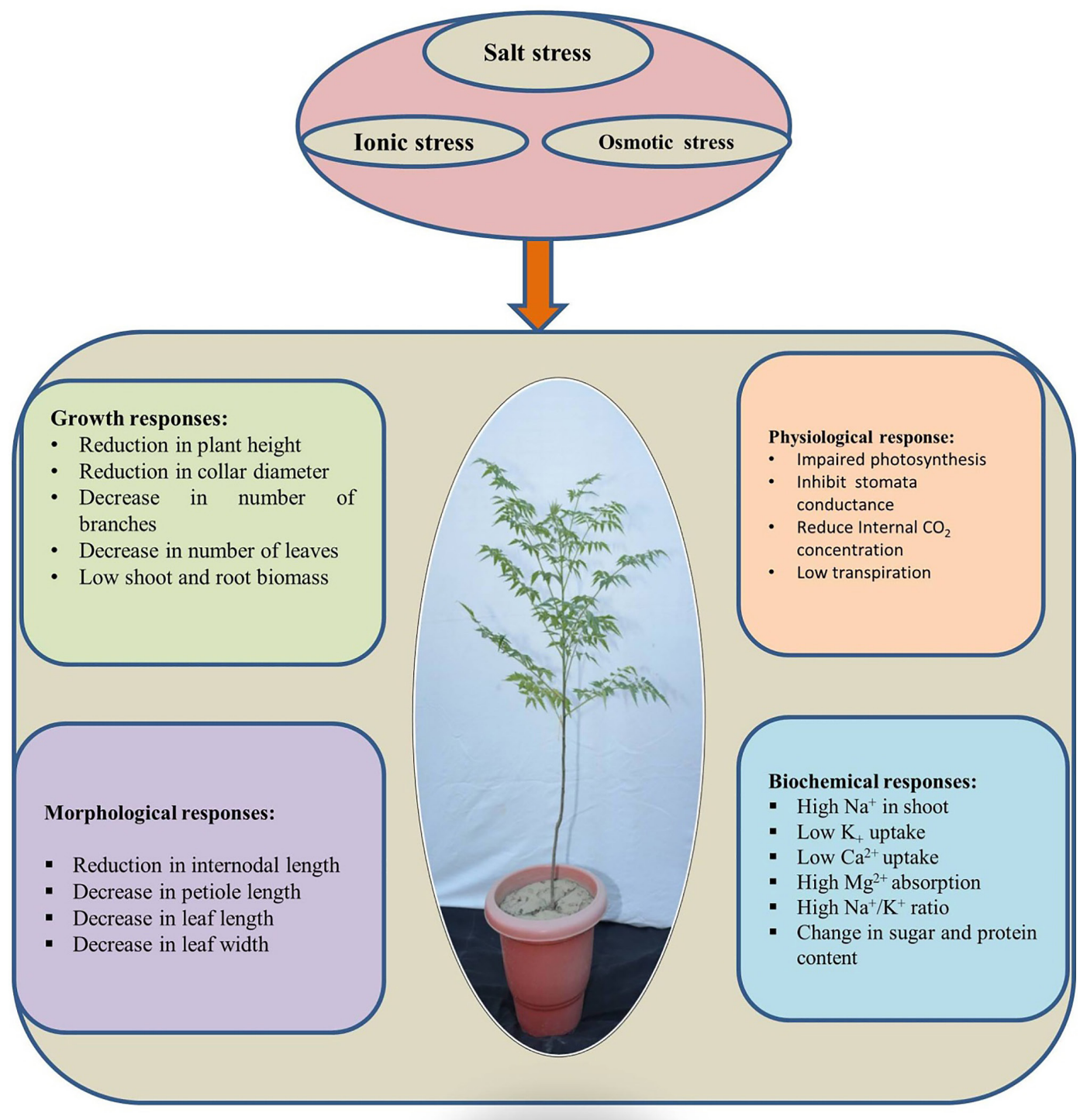

Fig. 6. Effect of salinity stress on growth, physiological, morphological and biochemical properties of $M$. dubia

chlorpophyll (Mittal et al., 2012). Our findings indicated that increase in salinity stress adversely affected the chlorophyll content, leading to decline in the photosynthetic rate, stomatal conductance, internal $\mathrm{CO}_{2}$ concentration, and transpiration rate, and the extent of the reduction was dependent on the salt strength. Zollinger (2007) also reported that salt-water irrigation adversely affects the photosynthetic rate and stomatal conductance in Echinacea purpurea. The alteration in physiological processes under salt stress can be attributed to the both stomatal and non-stomatal limitations (Thiem, 2020), as plants tend to close their stomata in response to the specific-ion accumulations. Results further explained that salt stress reduces the relative water content and enhances the stress injury that subsequently leads to decrease in the rate of photosynthesis, internal $\mathrm{CO}_{2}$ concentration and transpiration. Several previous studies have also highlighted the degradation of plants physiological processes with the increased accumulation of toxic ions under salt stress (Arias-Moreno et al., 2017; Gao et al., 2015; Shu et al., 2013; Mitsuya et al., 2000 \& Yamane et al., 2004). The adverse effect on physiological processes with increased salt stress leads to the reduction in total protein and sugar in the plant tissues.

It was noticed that salt stress modified the morphological parameters of $M$. dubia, and the increase in salinity stress caused reduction in the leaf length, leaf width, petiole length, and internodal length. The ionic imbalance and lesser water availability with increasing salinity levels adversely affected these parameters, which ultimately produces the alteration in physio-biochemical processes and morphological parameters of Melia. Similarly, Kotagiri and Kolluru (2017) reported that salt stress decreases the plant leaf area to make osmotic adjustment by carbohydrates accumulation in the tissues. As leaves are directly involved in regulating all the plant physiological processes, therefore, 
determining critical salinity tolerance level is crucial, and beyond which salinity stress severely affects these processes, leading to the adverse effect on the plant growth and development. In present study, upto EC $8 \mathrm{dS} / \mathrm{m}$, all the morphological parameters were non-significantly affected, above this, salinity had the significant negative effect on the various plant processes. Similarly, Yu et al. (2015) and Mzabri et al. (2017) also reported the adverse effect of salt stress on the plant morphological parameters. Results further explained that both the phenological parameters i.e. number of leaves and branches of Melia declined during each month with the increasing levels of salinity. The decrease in number of leaves and branches at EC 12 was more pronounced than the rest of EC levels and control. The greater uniformity in the saplings during initial months was responsible for depicting overlapping trends between the treatments for both the parameters. However, after November, as a consequence of salt stress, difference subsequently become more and more clear till the termination of experiment in April. The toxic effect of variable $\mathrm{Na}^{+}$ions concentration at each salinity level causes difference in the leaf and branch senescence (Munns \& James, 2003). The change in regional climate viz. summer, autumn, winter, and spring were responsible for monthly variation in the phenological parameters. Senescence (leaves and branches) was initiated during October and both was minimum during January (peak winter), afterwards their re-emergence initiated during mid-Febuary (spring season). Such change in phenological behavior under salt stress has been previously described in various crop plants (Kim et al., 2007; Leila et al., 2016). Moreover, in addition to climatic parameters, results explained that salt stress also played important role in regulating the plant phenology. The phenological changes under salt stress could potentially affect the plants reproductive biology and development processes (Ryu et al., 2014). Another interesting phenomenon observed was the post winter apical shoot and bud initiation, which might also serve as a good indicator of salt tolerance in the species. Delayed apical shoots initiation with increased salt stress might lead to substantial reduction in the plant growth during the growing season. Thus, timing of shoot initiation can indirectly provide idea about the range of salt tolerance and subsequent seasonal growth pattern in tree species. Moreover, understanding the relationship between environmental stress and plant phenology is vital for future genetic manipulation to increase plant productivity under the changing climate (Kazan \& Lyons, 2016). Therefore, alteration in the seedlings morphology and phenology under salt stress could affect the overall development processes in Melia.

We further observed the effect of salinity stress on growth and biomass of $M$. dubia to assess the species salt tolerance potential. Results showed that height and diameter growth were almost consistently declined in response to salt stress treatments. Under saline conditions, decrease in growth was non-significant up to EC $8 \mathrm{dS} / \mathrm{m}$, while significant at EC $12 \mathrm{dS} / \mathrm{m}$, indicating that M. dubia could successfully grow under moderate saline stress conditions. However, decrease in growth at EC $12 \mathrm{dS} / \mathrm{m}$ showed non-suitability of species at high salt stress $(>12 \mathrm{ds} / \mathrm{m})$ conditions. Results further showed that upto EC $8 \mathrm{dS} / \mathrm{m}$, this species can be grown successfully without any substantial reduction in growth and hence; upto these levels best benefits can be obtained from the species. It can be grown at EC 12 $\mathrm{dS} / \mathrm{m}$ with $20-30 \%$ reduction in the growth and biomass. Similar findings were reported by Banyal et al. (2018) who reported that growth increment in Melia decreases with the increased salinity stress. Although reduction in the trees growth with increased salt stress is well proven by the previous researchers in the region (Minhas et al., 1997; Tomar et al., 1998; Tomar et al., 2003; Singh et al., 2011). M. dubia, being industrially important species owing to its fast growth, greater ecological and economic benefits under pure plantation or agroforestry can be obtained within 7-8 years in such soils, except at the high salt stress. Specifically, at high salt stress, plantation restoration benefits will not be achieved in reasonable time period and best to the stakeholders' expectation in the absence of reclamation measures (Kumar et al., 2021a). Moreover, M. dubia has showed good growth potential in fertile, marginal and degraded soils conditions. Developing Melia based agroforestry practises/systems in salt affected soils could be helpful in enhancing the productivity, sustainability and climate resilience of agroecosystems (Newete et al., 2020). Standardization of plantation technology, cultural practises, water and nutrient management could further increase the species growth and productivity under salt stress. However, present findings needs to be confirmed and validated from the longterm field results for obtaining more precise information on the productivity and restoration potential of Melia in salt affected soils. Further, understanding physiological mechanism and undertaking genetic improvement work for enhancing salt tolerance might play important role in species success on the salt affected soils. Therefore, the salt tolerance of $M$. dubia showed strong potential in restoration and sustainable utilization of the salt affected soils.

\section{Conclusion}

The present study demonstrated an overview of the salinity stress effect on the growth and physio-biochemical responses of $M$. dubia. Based on the findings, 
we recommend $M$. dubia for salt affected soils of EC 8 $\mathrm{ds} / \mathrm{m}$ without any substantial effect on species growth rate and of EC $12 \mathrm{ds} / \mathrm{m}$ with $20-25 \%$ reduction in the growth rate. Therefore, the present outcome provided an insight into the salinity tolerance and change in physiological processes in the species which could be useful for devising the tree improvement strategies. Elucidating physiological mechanism, assessing biochemical changes, and identifying plant metabolites will provide ideas about species salt tolerance and futuristic strategies for developing salt tolerant crop through breeding and improvement approaches.

\section{Declarations}

\section{Funding}

This work is supported by ICAR-CSSRI, Karnal, and manuscript approved for publication wide reference no. PME/142/2020.

\section{Conflict of interest}

Author (s) doesn't have conflict of interest.

\section{Availability of data and material}

Raw data is available with ICAR-CSSRI, Karnal, India.

\section{Code availability \\ N.A.}

\section{Authors' contributions}

Raj Kumar: Conceptualization, Investigation, Data collection, Original draft preparation, Methodology. Rakesh Banyal: Investigation and data analysis. Awtar Singh: Investigation and editing. R K Yadav: Supervision and Editing. P C Sharma: Conceptualization and methodology.

\section{Compliance with ethical standards}

\section{Consent to participate and publication}

All authors given their consent for participation and publication.

\section{References}

Arias-Moreno DM, Jiménez-Bremont JF, Maruri-López I \& Delgado-Sánchez P (2017) Effects of catalase on chloroplast arrangement in Opuntia (streptacantha chlorenchyma) cells under salt stress. Scientific Reports 7: e8656. doi:10.1038/s41598017-08744-X.

Aron DI (1949) Copper enzymes isolated chloroplasts, polyphenoloxidase in Beta vulgaris. Plant Physiology 24: 1-15. doi:10.1104/pp.24.1.1.
Azooz MM, Metwally A \& Abou-Elhamd MF (2015) Jasmonate-induced tolerance of Hassawi okra seedlings to salinity in brackish water. Acta Physiologiae Plantarum 37: e77. doi:10.1007/s11738015-1828-5.

Banyal R, Kumar R, Kumar M, Yadav RK \& Dagar JC (2017) Agroforestry for rehabilitation and sustenance of saline ecologies: Agroforestry (ed. by J Dagar \& V Tewari) Springer, Singapore. doi:10.1007/978-981-10-7650-3_16.

Banyal R, Yadav RK, Sheoran P, Bhardwaj AK, Parveen K, Kumar R \& Tolia R (2018) Managing saline soils of Indo-Gangetic Plains with eucalyptus and melia based agroforestry systems. Indian Journal of Ecology 45: 841-849.

Barrs HD \& Weatherley PE (1962) A re-examination of the relative turgidity technique for estimating water deficits in leaves. Australian Journal of Biological Sciences 15: 413-428. doi:10.1071/ BI9620413.

Bhardwaj AK, Mishra VK, Arora S, Srivastava S, Singh YP \& Sharma DK (2019) Soil salinity and land use-land cover interactions with soil carbon in a salt-affected irrigation canal command of Indo-Gangetic plain. Catena 180: 392-400. doi:10.1016/j.catena.2019.05.015.

Bradford MM (1976) A rapid and sensitive method for the quantitation of microgram quantities of protein utilizing the principle of protein-dye binding. Analytical biochemistry 72: 248-254. doi;10.1016/0003-2697(76)90527-3.

Dagar JC (2014) Greening salty and waterlogged lands through agroforestry systems for livelihood security and better environment. Agroforestry systems in India: livelihood security \& ecosystem services (ed. by JC Dagar, AK Singh \& A Arunachalam) Advances in Agroforestry 10, Springer, Dordrecht, pp. 273-332. doi:10.1007/978-81322-1662-9.

Demidchik V \& Maathuis FJ (2007) Physiological roles of nonselective cation channels in plants: from salt stress to signalling and development. New Phytologist 175: 387-404. doi:10.1111/ j.1469-8137.2007.02128.x.

Dionisio-Sese ML \& Tobita S (1998) Antioxidant responses of rice seedlings to salinity stress. Plant Science 135: 1-9.

Flowers TJ (2004) Improving crop salt tolerance. Journal of Experimental Botany 55: 307-319. doi:10.1093/jxb/erh003.

Gao HJ, Yang HY, Bai JP, Liang XY, Lou Y, Zhang JL, Wang D, Zhang JL, Niu SQ \& Chen YL (2015) Ultrastructural and physiological responses of potato (Solanum tuberosum L.) plantlets to gradient saline stress. Frontier in Plant Science 5: 787. doi:10.3389/fpls.2014.00787. 
Gong HJ, Randall DP \& Flowers TJ (2006) Silicon deposition in the root reduces sodium uptake in rice (Oryza sativa L.) seedlings by reducing bypass flow. Plant Cell and Environment 29: 1970-1979. doi:10.1111/j.1365-3040.2006.01572.x.

Hassid WZ \& Neufeld EF (1964) Quantitative determination of starch in plant tissues. In: Whistler RL and BeMiller JN Eds) Methods of Carbohydrate Chemistry. Academic Press, New York, Vol. 6, pp. 33-36.

Hazman M, Hause B, Eiche E, Riemann M \& Nick P (2016) Different forms of osmotic stress evoke qualitatively different responses in rice. Journal of Plant Physiology 202: 45-56. doi:10.1016/j. jplph.2016.05.027.

Hilge $\mathrm{M}$ (2012) $\mathrm{Ca}^{2+}$ regulation of ion transport in the $\mathrm{Na}+/ \mathrm{Ca} 2+$ exchanger. Journal of Biological Chemistry 287: 31641-31649. doi:10.1074/jbc. R112.353573.

Kazan K \& Lyons R (2016) The link between flowering time and stress tolerance. Journal of Experimental Botany 67: 47-60. doi:10.1093/jxb/ erv441.

Kim SG, Kim SY \& Park CM (2007) A membrane-associated NAC transcription factor regulates salt-responsive flowering via flowering locus $\mathrm{T}$ in Arabidopsis. Planta 226: 647-654. doi:10.1007/ s00425-007-0513-3.

Kotagiri D \& Kolluru VC (2017) Effect of salinity stress on the morphology \& physiology of five different Coleus species. Biomedical \& Pharmacology Journal 10: 1639-1649. doi:10.13005/bpj/1275.

Kumar A, Savita, Shrivastava P, Sharma S, Dobhal S, Rana A \& Kumar R (2017) Development of gigh yielding varieties of Melia Dubia Cav. Indian forester 143: 1203-1206.

Kumar R, Bhardwaj AK, Rao BK, Vishavkarma AK, Bhatnagar PR, Patra S, Kumar G, Kakade V, Dinesh D, Pande V C, Singh G, Dobhal S \& Sharma NK (2020) Development of degraded ravine lands of Western India via Sapota (Achras zapota) plantation with terracing vs. trenching-on-slope based conservation measures. Land Degradation and Development 32: 101-111. doi:10.1002/ldr.3691.

Kumar R, Banyal R, Singh A, \& Yadav, RK (2021a) Exploring the genetic variation for sodicity tolerance in Melia dubia evolved in Indian conditions. Land Degradation \& Development, 1-14. doi:10.1002/ldr.4126.

Kumar R, Banyal R, Singh A (2021b) Growth and physiological responses of Melia plant (Melia dubia Cav.) to alkali stress. Journal of Natural Resource Conservation and Management. 2(1): 1725. doi:10.51396/ANRCM.2.1.2021.17-25.

Latef AAA \& Tran LSP (2016) Impacts of priming with silicon on the growth and tolerance of maize plants to alkaline stress. Frontiers in Plant Science 7: 43-54. doi:10.3389/fpls.2016.00243.

Leila R, Cristian DC, Teofilo V \& Leila R (2016) Effects of drought and salinity on maize phenology, morphology and productivity in a semi-arid environment. Italian Journal of Agrometeorology 21: 43-54. doi:10.19199/2016.3.2038-5625.043.

Lemos AFA, Ferreira DS, DaSilva EN \& Gomes DSJA (2008) Clones of dwarf-precocious cashew submitted to salt stress and the accumulation of potassium and sodium. Revista Ciencia Agronomica 39: 422-428.

Maathuis FJ (2009) Physiological functions of mineral macronutrients. Current Opinion in Plant Biology 12: 250-258. doi:10.1016/j.pbi.2009.04.003.

Minhas PS, Singh YP, Tomar OS, Gupta RK \& Gupta RK (1997) Saline water irrigation for establishment of furrow-planted trees in Northwest India. Agroforestry Systems 35:177-186. doi:10.1007/ BF00122778.

Mitsuya S, Takeoka Y \& Miyake H (2000) Effects of sodium chloride on foliar ultrastructure of sweet potato (Ipomoea batatas Lam.) plantlets grown under light and dark conditions in vitro. Journal of Plant Physiology 157: 661-667. doi:10.1016/ S0176-1617(00)80009-7.

Mittal S, Kumari N \& Sharma V (2012) Differential response of salt stress on Brassica juncea: Photosynthetic performance, pigment, proline, D1 and antioxidant enzymes. Plant Physiology and Biochemistry 54: 17-26. doi:10.1016/j.plaphy.2012.02.003.

Munns R \& James RA (2003) Screening methods for salinity tolerance: a case study with tetraploid wheat. Plant and Soil 253: 201-218. doi:10.1023/A:1024553303144. doi:10.1023/A:1024553303144.

Munns R \& Tester M (2008) Mechanisms of salinity tolerance. Annual Review of Plant Biology 59: 651-681.

Mzabri I, Legsayer M, Kouddane N, Boukroute A \& Berrichi A (2017) Salt stress effects on some morphological, physiological and biochemical parameters of saffron plant (Crocus sativus L.) in Eastern Morocco. Journal of Materials and Environmental Science 8: 4894-4901.

Parida AK, Veerabathini SK, Kumari A \& Agarwal PK (2016) Physiological, anatomical and metabolic implications of salt tolerance in the Halophyte Salvadora persica under hydroponic culture condition. Frontiers in Plant Science 7: 351. doi:10.3389/ fpls.2016.00351.

Parthiban KT, Bharathi AK, Seenivasan R, Kamala K \& Rao MG (2009) Integrating Melia dubia in agroforestry farms as alternate Pulpwood species. Asia-Pacific Agroforestry Newsletter 34. 
Ryu JY, Lee HJ, Seo PJ, Jung JH, Ahn JH \& Park CM (2014) The Arabidopsis floral repressor BFT delays flowering by competing with FT for FD binding under high salinity. Molecular Plant 7: $377-$ 387. doi: $10.1093 / \mathrm{mp} / \mathrm{sst} 114$.

Shu S, Yuan L, Guo S, Sun J \& Yuan Y (2013) Effects of exogenous spermine on chlorophyll fluorescence, antioxidant system and ultrastructure of chloroplasts in Cucumis sativus L. under salt stress. Plant Physiology and Biochemistry 63: 209-216. doi:10.1016/j.plaphy.2012.11.028.

Singh YP, Singh G \& Sharma DK (2011) Ameliorative effect of multipurpose tree species grown on sodic soils of Indo-Gangetic Alluvial Plains of India. Arid Land Research and Management 25: 55-74. doi: 10.1080/15324982.2010.528150.

Sjoman H, Levinsson A, Emilsson T, Ibrahimova A, Sjoman H, Levinsson A, Emilsson T, Ibrahimova A, Alizade V, Douglas P \& Wistrom B (2021) Evaluation of Alnus subcordata for urban environments through assessment of drought and flooding tolerance. Dendrobiology 85: 39-50. doi:10.12657/ denbio.085.005.

Thiem D, Tyburski J, Gołębiewski M \& Hrynkiewicz K (2020) Halotolerant fungi stimulate growth and mitigate salt stress in Alnus glutinosa Gaertn. Dendrobiology 83: 30-42. doi:10.12657/denbio.083.003.

Tomar OS, Gupta RK \& Dagar JC (1998) Afforestation techniques and evaluation of different tree species for waterlogged saline soils in semiarid tropics. Arid Soil Research and Rehabilitation 12: 301-316. doi:10.1080/15324989809381520.

Tomar OS, Minhas PS, Sharma VK, Singh YP \& Gupta RK (2003) Performance of 31 tree species and soil condition in a plantation established with saline irrigation. Forest Ecology and Management 177: 333-346.

USSLS (1954) US Salinity Laboratory Staff. Diagnosis and improvement of saline and alkali soils. US Department of Agriculture, Handbook 60.
Yamane K, Rahman MS, Kawasaki M, Taniguchi M \& Miyake H (2004) Pretreatment with antioxidants decreases the effects of salt stress on chloroplast ultrastructure in rice leaf segments (Oryza sativa L.). Plant Production Science 7: 292-300.

Yemm EW \& Willis A (1954) The estimation of carbohydrates in plant extracts by anthrone. Biochemical Journal 57: 508-514. doi:10.1042/ bj0570508.

Yu X, Liang C, Chen J, Qi X, Liu Y \& Li W (2015) The effects of salinity stress on morphological characteristics, mineral nutrient accumulation and essential oil yield and composition in Mentha canadensis L. Scientia Horticulturae 197: 579-583. doi:10.1016/ j.scienta.2015.10.023.

Yuan Y, Brunel C, Kleunen M, Junmin L \& Jin Z (2019) Salinity-induced changes in the rhizosphere microbiome improve salt tolerance of $\mathrm{Hi}$ biscus hamabo. Plant and Soil 443: 525-537. doi:10.1007/s11104-019-04258-9.

Zhang J (2014) Coastal saline soil rehabilitation and utilization based on forestry approaches in China. Berlin-Heidelberg, Springer. pp.145-164.

Zhang X, Takano T \& Liu S (2006) Identification of a mitochondrial ATP synthase small subunit gene (RMtATP6) expressed in response to salts and osmotic stresses in rice (Oryza sativa L.). Journal of Experimental Botany 57: 193-200. doi:10.1093/ jxb/erj025.

Zhao Q, Suo J, Chen S, Jin Y, Ma X, Yin Z, Zhang Y, Wang T, Luo J, Jin W, Zhang X, Zhou Z \& Dai S (2016) $\mathrm{Na}_{2} \mathrm{CO}_{3}$-responsive mechanisms in halophyte Puccinellia tenuiflora roots revealed by physiological and proteomic analyses. Scientific Reports 6: 32717. doi:10.1038/srep 32717.

Zollinger N, Koenig R, CernyKoenig T \& R Kjelgren (2007) Relative salinity tolerance of intermountain Western United States native herbaceous perennials. Hort Science 42: 529-534. doi:10.21273/ HORTSCI.42.3.529. 